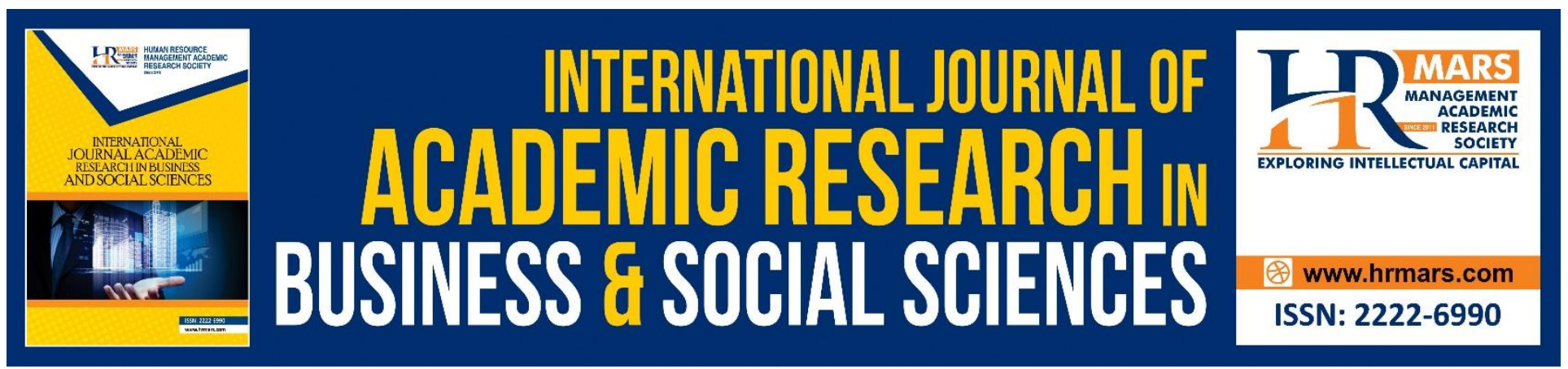

\title{
The Macroeconomic Determinants of Household Debt in Malaysia
}

Suhana Mohamed, Siti Sara Mohamadon, Wan Muhd Faez Wan Ibrahim, Ferri Nasrul, Siti Salwa Hassan, Mohamad Azwan Md Isa, Mohd Khairul Ariff Noh

To Link this Article: http://dx.doi.org/10.6007/IJARBSS/v10-i5/7425

DOI:10.6007/IJARBSS/v10-i5/7425

Received: 05 February 2020, Revised: 29 March 2020, Accepted: 09 April 2020

Published Online: 28 May 2020

In-Text Citation: (Mohamed et al., 2020)

To Cite this Article: Mohamed, S., Mohamadon, S. S., Ibrahim, W. M. F. W., Nasrul, F., Hassan, S. S., Isa, M. A. M., \& Noh, M. K. A. (2020). The Macroeconomic Determinants of Household Debt in Malaysia. International Journal of Academic Research in Business and Social Sciences, 10(5), 987-1000.

\section{Copyright: (C) 2020 The Author(s)}

Published by Human Resource Management Academic Research Society (www.hrmars.com)

This article is published under the Creative Commons Attribution (CC BY 4.0) license. Anyone may reproduce, distribute, translate and create derivative works of this article (for both commercial and non-commercial purposes), subject to full attribution to the original publication and authors. The full terms of this license may be seen

at: http://creativecommons.org/licences/by/4.0/legalcode

Vol. 10, No. 5, 2020, Pg. 987 - 1000

http://hrmars.com/index.php/pages/detail/IJARBSS

JOURNAL HOMEPAGE

Full Terms \& Conditions of access and use can be found at http://hrmars.com/index.php/pages/detail/publication-ethics 


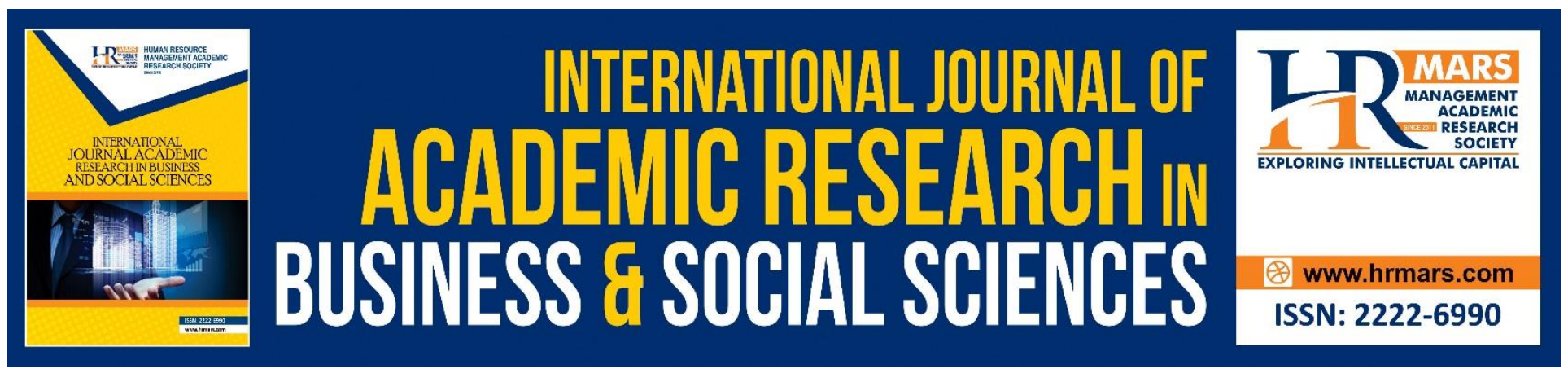

\title{
The Macroeconomic Determinants of Household Debt in Malaysia
}

\author{
Suhana Mohamed, Siti Sara Mohamadon \\ Department of Finance, Faculty of Business and Management, Universiti Teknologi MARA, Johor \\ Branch, Pasir Gudang Campus, Malaysia
}

\section{Wan Muhd Faez Wan Ibrahim}

Department of Finance, Faculty of Business and Management, Universiti Teknologi MARA, Sarawak Branch, Malaysia

\section{Ferri Nasrul}

Department of Finance, Faculty of Business and Management, Universiti Teknologi MARA, Johor

Branch, Segamat Campus, Malaysia

\section{Siti Salwa Hassan}

Department of Finance, Faculty of Business and Management, Universiti Teknologi MARA, Sarawak Branch, Malaysia

\section{Mohamad Azwan Md Isa, Mohd Khairul Ariff Noh}

Department of Finance, Faculty of Business and Management, Universiti Teknologi MARA, Johor

Branch, Segamat Campus, Malaysia

\section{Abstract}

The number of household debt in Malaysia continue to increase and seen as one of the effects of the unstable Malaysian economy. Consequently, authors motivated to do the study that focuses on analyzing the debt offered to the consumer. The research paper aims to examine the relationship and impact of macroeconomic determinants or variables on household debt in Malaysia and to determine the most significant factor that affects household debt. The study used the annual secondary data from 1984 to 2018, taken from reliable sources; Databank, Knoema, Bloomberg, and Bank Negara Malaysia. Three macroeconomic determinants used; Gross Domestic Product (GDP), Unemployment Rate (UN-EM), and Inflation Rate (INF). The relationship between macroeconomic determinants and household debt is analyzed using Econometric method namely Descriptive Analysis, Augmented Dickey Fully (ADF), Unit Root Test, Philips-Perron (PP) Unit Root Test, Normality Test, and Regression Analysis. Based on the multiple Regression Model Test, the results showed that 
all the three variables; the GDP, UN-EM and INF, have direct relationships with or pose positive impacts on the household debt. The UN-EM showed the largest and followed by the GDP. The finding indicates that the rise of these independent variables determines the rise of household debt. Only the GDP and UN-EM are significant determinants, while INF is found insignificant. Findings of this study reinforced that the household uses the debt as a substitute for income to finance the rising consumption due to the higher cost of living. The findings demonstrate that the debt level is high and show the actual national struggles. As a recommendation, the future researcher could use different data structure, research on other countries and add more macroeconomic variables.

Keywords: Household Debt, Macroeconomic, Determinants, Factors, Financing.

\section{Introduction}

The increasing of household debt has drawn attention for policymakers, academicians and economists to push for further research. High level of household debt measuring as a ratio household debt to Gross Domestic Product indicates a cause of instability and lower economic growth (Mian, Sufi, \& Verner, 2016).

In 2018, Malaysia's household debt stood at RM1.18 trillion. The most significant percentage of this debt is residential housing loan amounted to RM628 million accounted for 53.2 per cent of the total household debt. The percentage of household debt to the gross domestic product in Malaysia remained higher at 82.2 per cent in 2019 (The Star, 2019).

The rising household and personal debt have led to unprecedented numbers of people filing for bankruptcy, which undermines the intended benefits of such credit availability (Azma, Rahman, Adeyemi \& Rahman, 2019).

Many Malaysian households have limited savings and relatively low incomes. In the Malaysian context, ease of getting credit, increases in payment periods and use of credit cards instead of cash contributed to the increasing number of consumption and indebtedness in Malaysia (Endut and Hua, 2009). Zainol et al. (2016) shared that the household debt in Malaysia has increased from RM465.2bn in 2008 to RM1,010.8bn in 2015.

The study aims to identify the relationship between household debt and its variables and to determine the significant variable affecting household debt. Three variables used are the Gross Domestic Product (GDP), Unemployment Rate (UN-EM) and Inflation Rate (INF).

\section{Literature Review}

Household debt is a new issue that is growing excessively in both developed and developing countries. The issue triggered and raised concerns by the economist as it leads to the risk of financial instability (World Bank, 2014). Past researchers conducted studies on a household debt with various determinants used. Based on that, the macroeconomics determinants that gave impact to household debt used for this study were Gross Domestic Product (GDP), Unemployment Rate (UN-EM) and Inflation Rate (INF). 


\section{Household Debt}

Household debt is a debt which requires payment; payments of interest; principal to the creditor at a date and in the future for all the liabilities. Households borrow for several reasons, such as for saving; for overdue consumption or to purchase a house (Azwani, Nabihah, and Zuraida, 2019). Thus, having debt helps to make resource allocation more efficient and improve standards of living by bringing forward consumption and investment.

The rise of household debt has increased concern to the government and household sectors. This issue has also attracted the researchers to conduct the study and investigate the factors or determinants that impact the household debt in Malaysia (Yahaya and Sarwe, 2019). The debt also gave a negative impact and creates vulnerabilities to financial stability when the level of household debt is high (Charpe and Flaschel, 2013).

However, the introduction of Maqasid Al-Shariah helps to solve financial imbalances sees as a helping hand in stabilizing the economy before GDP growth targets calculated (Meniago, Petersen, Petersen, and Mongale, 2013). The issues of the principle of household debt and finance according to the Islamic economic perspective and finding are the principle of debt and finance according to Islam for households, and financial institutions also being discussed thoroughly by researchers (Yun Kim, 2011).

\section{Household Debt and Gross Domestic Product}

Gross Domestic Product defined as the market value of all final goods and services produced in countries for one year. The real GDP solves the nominal GDP problem, which is GDP increases yearly, but output has not increased, by correcting the prices. It compares the actual yearly number from real GDP, which easier to determine and has real changes in output (Yahaya and Sarwe, 2019).

Khans et al. (2016), revealed the connection between household debt and GDP in Malaysia using the non-causality theory. GDP and household debt are closely related, either in the short term or in the long term (Nieto, 2007). The researcher found that positive economic growth reflects higher GDP where households earned more incomes and banks issue additional debt. The household debt in Malaysia act as a proxy for income (Oikarinen, 2008).

\section{Household Debt and Unemployment Rate}

The unemployment rate in Malaysia is stable at three per cent, which means the population is experiencing somewhere close to full employment. The Statistic portal proved that the country achieved its lowest unemployment rate in 2014, with a rate of 2.85 per cent. The vibrant economy of Malaysia is considered one of the strongest in South - East Asia (Yahaya and Sarwe, 2019).

Unemployment rate denotes to the number of unemployed people; a percentage of the labour force comprises of the unemployed and that self-employment (Gerlach and Peng, 2004). Jan, Grzegorz and Alena (2017) stated that unemployment has a negative short-term relationship. The households tend to increase borrowing due to increased spending or low unemployment (Meniago, Petersen and Mongale, 2013). About one-third of total unemployment rises in Spain can be traced back to high levels of household debt. 
Hair et al. (2012) found that unemployment will create labour market uncertainty and prevent households from borrowing money. Financial bodies will also avoid debt issuance. Haishan (2014) concluded that a high level of unemployment means that there is less income for all households and a stronger desire for consumer financing loans which increases the possibility of financial constraints and discourages households from borrowing because households may not be able to repay loans.

Jauch and Watzka (2013) investigated the effect of household deleveraging on unemployment in Spanish and found that an increase in household debt found to be significantly affected by positive changes in unemployment. In a different study, Catherine et al. (2016) revealed that unemployment rate is a positive and significant relationship with household debt because they found that temporary unemployment situation would also compel households to increase debt when they have to maintain their current living standards.

The unemployment rate also has a negative and significant relationship on household debt (Meng et al., 2013; Hoang and Meng, 2015 and Masturah et al., 2016). A study by Meng et al. (2013) about the determinants of Australian household debt suggests the unemployment rate is one of the leading factors which explains the rising household debt level in Australia. Defaults on payments will occur as borrowers will find it challenging to maintain their mortgage payments during periods of unemployment (Hoang and Meng, 2015).

\section{Household Debt and Inflation Rate}

Inflation is the rate at which the general level of prices for goods and services is rising; which in return, the purchasing power of currency is falling. Mutezo (2014), Zimunya and Raboloko (2015) and Nomatye and Phiri (2017) used this determinant in their studies. The inflation has positive and significant in influencing household debt which is supported only by Mutezo (2014). The reason is when the reserve bank is cleverly controlling the interest rate in the event of inflation going up, and South Africa households will be burdened by debts that they will not be able to pay.

Contradict with the study above, and inflation also can be harmful and significant related to the household debt (Meng et al., 2013 and Catherine et al., 2016). They argued that higher inflation would reduce the household's ability to borrow. Concerning borrowing, inflation will devalue the debt, providing a strong stimulus for households to borrow.

The inflation also can be found insignificantly related to household debt by Nomatye and Phiri (2017) and Zimunya and Raboloko (2015) where they found that inflation has a relationship with the household debt insignificantly by investigating the macroeconomic determinants of household debt in South Africa.

\section{Theoretical Framework}

The theoretical framework for this study is in the following figure. 
INTERNATIONAL JOURNAL OF ACADEMIC RESEARCH IN BUSINESS AND SOCIAL SCIENCES Vol. 10, No. 5, May, 2020, E-ISSN: 2222-6990 @ 2020 HRMARS

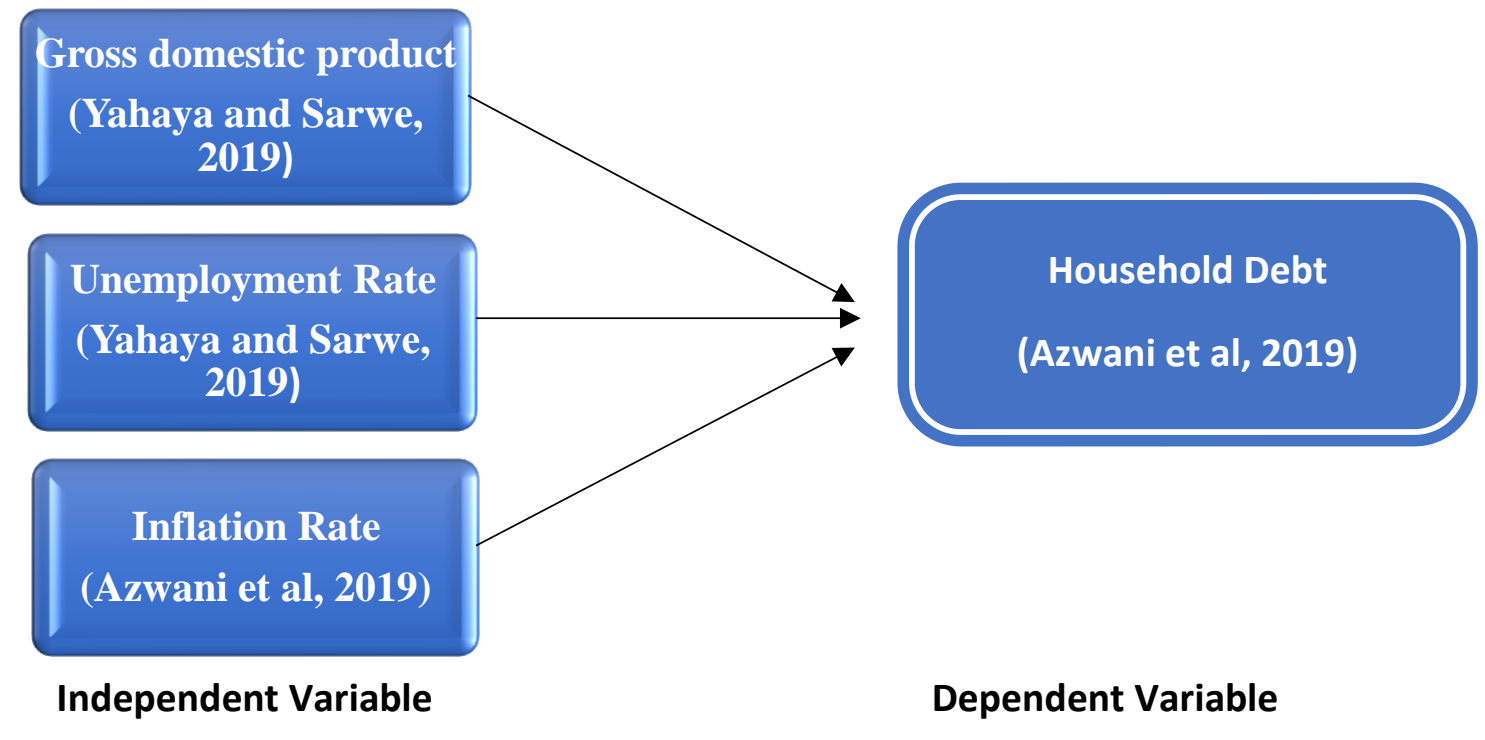

Figure 1. Theoretical Framework for the study (Azwani et al., 2019; Yahaya and Sarwe, 2019). The hypothesis developed for this study are as follows:

$\mathrm{H}_{1}=$ There is a significant relationship between independent variables (gross domestic product, unemployment and inflation) and household debt in Malaysia.

$\mathrm{H}_{2}=$ There is a significant relationship between variables

\section{Research Methodology}

Descriptive analysis is the first analysis done and used to describe the basic features of the data in this study. It provides simple summaries about the sample and the measures. With the aid of simple graphics analysis, the data presented as a form of the virtual basis for every quantitative analysis (Nick, 2007).

The observation data for each variable based on secondary data taken between 1984 to 2018, which ranged about 35 years using Eviews 10 software. This study focuses on three selected independent variables, namely, Gross Domestic Product (GDP), Unemployment Rate (UN-EM) and Inflation Rate (INF) and the dependent variable is Household Debt (HD). Data taken from reliable sources; Databank, Knoema, Bloomberg, and Bank Negara Malaysia.

The test for non-stationarity of data is also known as the unit root test. The Augmented Dickey-Fuller (ADF) test is a unit root test for stationarity. Unit roots can cause unpredictable results in time series analysis and a compulsory test to do.

Multiple Regression model analysis used in this study to find the relationship between variables. TTest or theory of hypothesis statement used to know whether to reject or not to reject the null of the hypothesis. It is a multivariate technique that is used very often in business research. The formula derived for this study as the following

$$
H D_{i}=\beta_{0}+\beta_{1} G D P_{i}+\beta_{2} U_{N E M}+\beta_{3} I N F_{i}+\varepsilon_{i}
$$


INTERNATIONAL JOURNAL OF ACADEMIC RESEARCH IN BUSINESS AND SOCIAL SCIENCES

Vol. 10, No. 5, May, 2020, E-ISSN: 2222-6990 @ 2020 HRMARS

Multiple regression analysis provides a means of objectively assessing the degree and the character of the relationship between the independent variables and the dependent variable. The regression coefficient indicates the relative importance of each independent variable in the prediction of the dependent variable (Sekaran and Bougie, 2013).

\section{Findings and Analysis}

The study used the Gross Domestic Product, Unemployment Rate and Inflation Rate as an independent variable to examine the relationship and impact on the dependent variable, which is Household Debt.

\section{Descriptive Analysis}

Table 1 summarizes the essential descriptive statistics of all observations for each variable, respectively.

Table 1. Descriptive Analysis

\begin{tabular}{|l|c|c|c|}
\hline & GDP & UN-EM & INF \\
\hline Mean & 5.533012 & 3.980000 & 3.157833 \\
\hline Median & 5.788499 & 3.430000 & 3.633484 \\
\hline Maximum & 10.00270 & 8.290000 & 10.38876 \\
\hline Minimum & -7.359415 & 2.450000 & -8.717320 \\
\hline Std. Dev. & 3.728365 & 1.496130 & 4.030578 \\
\hline Jarque-Bera & 23.54706 & 18.18851 & 5.732402 \\
\hline Probability & 0.000008 & 0.000112 & 0.056915 \\
\hline
\end{tabular}

As illustrated in Table 1, the highest mean scores for this study is 5.533012, while the lowest mean rating was 3.157833. The average score of the Gross Domestic Product was 5.533012, reflecting that increase household debt in Malaysia. It also can be observed that the lowest mean score is Inflation Rate 3.157833, indicated that this variable was the least factor that influences household debt in Malaysia. Unemployment Rate is the second important factor that influences household debt in Malaysia as the mean score is 3.98 .

In term of p-value showed Gross Domestic Product and Unemployment Rate showed significantly impact the Household Debt with 0.000008 and 0.000112 values, respectively. Contrast with Inflation rate $p$-value is 0.056915 , which means the $p$-value is not significant.

Therefore, Descriptive Analysis shows that two macroeconomic variables, namely Gross Domestic Product and Unemployment Rate, are significant; meanwhile, the probability for Inflation Rate is not significant.

\section{Compulsory Test Analysis}

The Augmented-Dickey Fuller (ADF) and Phillips-Perron (PP) used to test the unit root of the data. Tables 2 show the results from the unit root tests for the three variables studied. 
INTERNATIONAL JOURNAL OF ACADEMIC RESEARCH IN BUSINESS AND SOCIAL SCIENCES Vol. 10, No. 5, May, 2020, E-ISSN: 2222-6990 ㄷ 2020 HRMARS

Table 2: Unit Root Test using Augmented Dickey-Fuller (ADF) and Phillips-Perron (PP)

\begin{tabular}{|c|c|c|c|c|}
\hline & \multicolumn{2}{|c|}{ Augmented } & Dickey-Fuller & \multicolumn{2}{c|}{ Phillips } & \multicolumn{2}{l|}{ Perron } \\
\hline Variable & Level & $1^{\text {st }}$ Different & Level & $1^{\text {st }}$ Different \\
\hline HD & 0.0005 & $0.0000^{*}$ & 0.0043 & $0.0000^{* *}$ \\
\hline GDP & $0.0006^{*}$ & $0.0000^{*}$ & $0.0006^{*}$ & $0.0000^{* *}$ \\
\hline UNEM & 0.8394 & $0.0122^{*}$ & 0.7981 & $0.0090^{* *}$ \\
\hline INF & $0.0000^{*}$ & $0.0000^{*}$ & $0.0000^{*}$ & $0.0001^{* *}$ \\
\hline
\end{tabular}

The results for both ADF and PP test showed that the $p$-values of all three variables are stationary at 5 per cent of the significance level.

As shown in Figure 2, the p-value for the Jarque-Bera Test is 0.126013 , which means that the error term normally distributed.

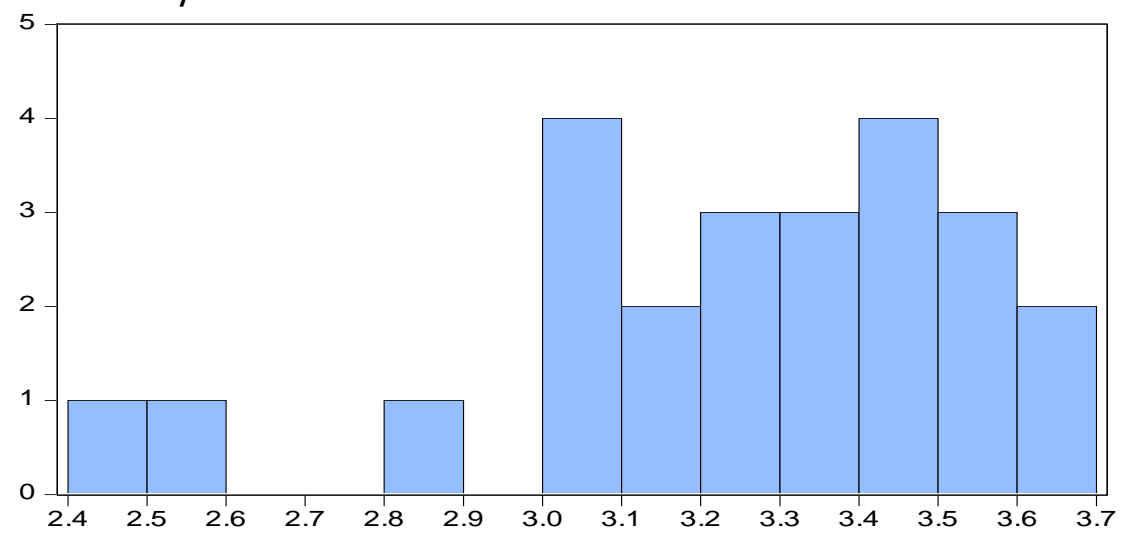

\begin{tabular}{|c|c|}
\hline \multicolumn{2}{|c|}{$\begin{array}{l}\text { Series: HD } \\
\text { Sample } 135 \\
\text { Observations } 35\end{array}$} \\
\hline Mean & 3.235417 \\
\hline Median & 3.285000 \\
\hline Maximum & 3.690000 \\
\hline Minimum & 2.450000 \\
\hline Std. Dev. & 0.312103 \\
\hline Skewness & -0.967925 \\
\hline Kurtosis & 3.628670 \\
\hline Jarque-Bera & 4.142744 \\
\hline Probability & 0.126013 \\
\hline
\end{tabular}

Figure 2. Normality Test

As illustrated in Table 3, Household Debt has a linear relationship or correlation with all the independent variables, which are Gross Domestic Product, Unemployment Rate and Inflation Rate.

Table 3: Correlation matrix for all variables

\begin{tabular}{|c|c|c|c|c|}
\hline Probability & HD & GDP & UN-EM & INF \\
\hline HD & 1.000000 & & & \\
& ----- & & & \\
\hline GDP & 0.776815 & 1.000000 & & \\
& 0.0000 & ---- & & \\
\hline UNEM & -0.282574 & -0.083441 & 1.000000 & \\
& 0.0111 & 0.6443 & ---- & \\
\hline INF & 0.432131 & 0.310377 & -0.273256 & 1.000000 \\
& 0.0120 & 0.0788 & 0.1239 & ---- \\
\hline
\end{tabular}


INTERNATIONAL JOURNAL OF ACADEMIC RESEARCH IN BUSINESS AND SOCIAL SCIENCES Vol. 10, No. 5, May, 2020, E-ISSN: 2222-6990 @ 2020 HRMARS

\section{Regression Analysis}

Based on Table 4, only gross Domestic Product and Unemployment Rate show a positive relationship with the Household Debt. The p-value for Gross Domestic Product is 0.0000 and unemployment Rate is 0.0228 is significant at 5 per cent significance level. The different result shows a positive relationship between Inflation Rate and Household Debt, but the p-value is not significant at 0.1707, which is more than 5 per cent of significant level.

Table 4: Regression Model

\begin{tabular}{|c|c|c|c|c|}
\hline Variable & Coefficient & Std. Error & t-Statistic & P-Value \\
\hline C & -12.88687 & 5.618250 & -2.293751 & 0.0328 \\
\hline GDP & 1.179065 & 0.141104 & 8.356010 & 0.0000 \\
\hline UN-EM & 4.002566 & 1.623273 & 2.465737 & 0.0228 \\
\hline INF & 0.072281 & 0.126691 & 0.570525 & 0.1707 \\
\hline
\end{tabular}

\section{Discussion}

This study investigates the impacts of three standard macroeconomic variables, namely the gross domestic product, unemployment rate and inflation rate towards household debt in Malaysia using annual data spanning from 1984 to 2018. Both the ADF and PP unit root tests confirm that each variable data series are stationary or integrated at the first difference.

Further, the Pearson's correlation test suggests that all three independent variables are significant, where the GDP and inflation rate pose a medium to high positive correlations while the unemployment rate indicates low negative correlation with the household debt, respectively.

The findings indicate that when a country's economic activities grow and develop, this will uplift the income level of the households, eventually spurs the demand for banks' financing or loans to meet their personal needs or wants. On the other hand, the rising inflation rate will contribute towards a hike in the prices of goods and services.

Despite the rising income level, the households' purchasing power might be deteriorating, which is suppressed by rises in inflation. Consequently, the households will go for banks' loans or financing as substitutes to cover the financial shortage. As for the unemployment rate, which indicates negative correlation indirectly showed that the more number of citizens or households are unemployed, the lesser demand for banks' loans or financing due to incapability to repay in the future.

Meanwhile, the multiple regression test reveals that only the GDP and unemployment rate are significant variables, whereas the inflation rate is not. In term of effects, all three variables affect the household debt positively, where unemployment shows the most significant effect on household debt and followed by the GDP. Inflation merely has minimal impact on household debt.

The finding on the GDP is consistent with Nizar (2015), who revealed that an increase in GDP reflects positive economic growth, which has a relationship with household debt in the short or long run. Due to the rise in households' income, this encourages the banks to issue more loans. The result on the 
INTERNATIONAL JOURNAL OF ACADEMIC RESEARCH IN BUSINESS AND SOCIAL SCIENCES

Vol. 10, No. 5, May, 2020, E-ISSN: 2222-6990 ㄷ 2020 HRMARS

GDP also supports Meniago, Petersen, Petersen and Mongale (2013), who concluded the significant and positive relationship between household debt and GDP.

When the GDP increases, this will encourage households to borrow more and cause household debt to increase. These findings are in line with the model that states higher GDP indicates higher economic growth and followed by higher income, which means that households and creditors will feel confident in taking and issuing more debts.

The finding on unemployment is consistent with the previous study by Jauch and Watzka (2013) that claimed an increase in household debt found to be significantly affected by positive changes in unemployment. The result of this study is also in support of Catherine et al. (2016), who revealed that the unemployment rate has a positive and significant relationship with household debt. They further discovered that temporary unemployment would also force households to increase debt when they have to maintain their current standards of living.

As for the inflation rate, our study shares a similar finding with Nomatye and Phiri (2017), who evidenced that inflation has a relationship but insignificant with the household debt in South Africa. Another study by Zimunya and Raboloko (2015) also proved that inflation is insignificantly related to household debt. By considering the inflation premium in the real interest rates, the tendency of inflation to stimulate demand for credits is cancelled out by the increase in the nominal interest rates; hence the net effect of inflation is not significant (Zimunya and Raboloko, 2015).

\section{Conclusion}

In conclusion, the research proposing to the policymakers to plan, strategize and enhance the economic policies. The related government agencies should revise and improve the existing economic policies, which are not effective or not contributing sufficiently to the increase in GDP or economic growth. If the foreign workers' policy tightened then the country may reduce the dependency on foreign labours.

As an alternative, the job positions must be filled in by the local citizens with equal salary and incentives in equivalent to the rising cost of living. Besides, action plans must be undertaken by the related agencies to ensure that enough job opportunities openly created in the economic sectors that are involved in high-tech and strategic industries. These steps are crucial to fight the unemployment issue.

Also, the related government agencies should come up with appropriate mechanisms to monitor the industries and suppliers of goods and services from charging too high prices on their products. Both parties must work closely in order to ensure the prices of goods and services are in control and ultimately could curb the inflation to escalate.

Finally, we suggest to the banking or lending institutions to develop flexible and attractive credit or debt facilities at reasonable costs that will contribute towards a 'win-win' situation to both lenders and borrowers, in particular, the households. 
INTERNATIONAL JOURNAL OF ACADEMIC RESEARCH IN BUSINESS AND SOCIAL SCIENCES

Vol. 10, No. 5, May, 2020, E-ISSN: 2222-6990 @ 2020 HRMARS

For future research, we recommend using a different data structure such as panel data based on daily, weekly, quarterly or monthly. The data set separated using several sub-periods or known as panel data such as pre, during and post-financial crises periods.

The results will be more meaningful if future research could also study a comparison with other countries either developed, developing or third world countries. Last but not least, adding more macroeconomic variables will generate more holistic picture to the future study.

\section{Acknowledgement}

Kudos to all authors for time, cooperation and commitment in completion and reviewing of the research paper.

\section{Corresponding Author}

Suhana Mohamed.

Department of Finance, Faculty of Business and Management, Universiti Teknologi MARA, Johor Branch, Pasir Gudang Campus, Jalan Purnama, Bandar Seri Alam, 81750 Masai, Johor, Malaysia.

Email: suhan291@uitm.edu.my.

\section{References}

Alan, T. (2018). Food for Thought: Restructuring Our Household Debt. The Star. Retrieved from https://www.thestar.com.my/business/business-news/2018/02/10/restructuring-ourhousehold-debt

Aini, A. N. (2018). Application of the Concept of Maslahah in Household Debt Management. In W. A. W. Marhaini \& A. A. Rahman (Eds.), New Developments in Islamic Economics, Emerald Publishing, 19-33.

Azma, N., Rahman, M., Adeyemi, A., \& Rahman, M. (2019). The propensity toward indebtedness: evidence from Malaysia. Review of Behavioral Finance, 11(2), 188-200.

Azureen, N., Rahman, A., Kosim, Z., \& Yeok, S. G. (2016). Household Indebtedness in Malaysia : A Survey Evidence. International Journal of Trade, Economics and Finance, 7(4), 102-104.

Azwani, N., Azmin, M., Nabihah, W., Zaidi, W., \& Mohamad, Z. (2019). The Determinants of Household Debt Case in Malaysia. In the 2nd International Conference on Islamic Economics, Business, and Philanthropy (ICIEBP), 2019, 1215-1226.

Betti, G., Dourmashkin, N., Rossi, M., \& Yin, P. Y. (2007). Consumer over-indebtedness in the EU: measurement and characteristics. Journal of Economic Studies, 34(2), 136-156

Catherine, S. F. H., Jamaliah, M. Y., Aminah, M., \& Arshad, A. (2016). Household Debt, Macroeconomic Fundamentals and Household Characteristics in Asian Developed and Developing Countries. The Social Sciences, 11, 4358-4362.

Charpe, M., \& Flaschel, P. (2013). Workers' debt, default and the diversity of financial fragilities. Structural Change and Economic Dynamics, 27, 48-65.

Crawford, A., \& Faruqui, U. (2012). What Explains Trends in Household Debt in Canada. Bank of Canada Review, Bank of Canada, 2011(Winter), 3-15.

Datta, S., Tiwari, A., \& Shylajan, C. (2018). An empirical analysis of nature, magnitude and determinants of farmers' indebtedness in India. International Journal of Social Economics, 45(6), 888-908. 
INTERNATIONAL JOURNAL OF ACADEMIC RESEARCH IN BUSINESS AND SOCIAL SCIENCES

Vol. 10, No. 5, May, 2020, E-ISSN: 2222-6990 @ 2020 HRMARS

Debelle, G. (2004). Macroeconomic Implications of Rising Household Debt (June 2004). BIS Working Paper No. 153.

Endut, N., \& Hua, T. G. (2009). Household debt in Malaysia. BIS Papers No. 46, Bank for International Settlements Communications, 107-116.

Gerlach, S., \& Peng, W. (2004). Bank lending and property prices in Hong Kong. Journal of Banking and Finance, 29, 461-481.

Hair, J. F., Sarstedt, M., Pieper, T. M., \& Ringle, C. M. (2012). The Use of Partial Least Squares Structural Equation Modeling in Strategic Management Research: A Review of Past Practices and Recommendations for Future Applications. Long Range Planning, 45(5-6), 320- 340.

Haishan, Fu. H. F. (2014). World development factors in 2014. Retrieved from The World Bank website: https://openknowledge.worldbank.org/ handle/10986/18237

Iacoviello, M. (2008). Household Debt and Income Inequality, 1963 - 2003. Journal of Money, Credit and Banking, 40(5), 929-965.

Jan, B., Grzegorz, M., \& Alena, A. (2017). Macroeconomic factors impact on the volume of household savings in the V4 countries. Journal of Applied Economic Sciences, 12(5/51), 1409-1421.

Jauch, S., \& Watzka, S. (2013). The Effect of Household Debt Deleveraging on Unemployment Evidence from Spanish Provinces. In Annual Conference 2013 (Duesseldorf): Competition Policy and Regulation in a Global Economic Order, 1-45.

Jeong, H., Lee, D., Chil, J., \& Kyu, M. (2014). Japan and the World Economy Household indebtedness in Korea : Its causes and sustainability. Japan \& The World Economy, 29(Jan. 2014), 59-76.

Khan, H. H. A., Abdullah, H. \& Samsudin, S. (2016). Modelling the Determinants of Malaysian Household Debt. International Journal of Economics and Financial Issues, 6(4), 1468-1473.

Keen, S. (2009). Household Debt Household Debt : The Final Stage in an Artificially Extended Ponzi Bubble. Australian Economic Review, 42(3), 347-357.

Keese, M. (2012). Who feels constrained by high debt burdens ? Subjective vs objective measures of household debt. Journal of Economic Psychology, 33(1), 125-141.

Kukk, M. (2017). How does household debt affect financial asset holdings? Evidence from euro area countries. Studies in Economics and Finance, 34(2), 194-212.

Loke, Y. (, 2015). Living beyond one's means: evidence from Malaysia. International Journal of Social Economics, 43(1), 2-18

Ma, M., Amira, N., Tajuddin, I., Badariah, S., \& Nathan, S. (2016). Household Debt and Macroeconomic Variables in Malaysia. In $3^{\text {rd }}$ International Conference on Business and Economics, 21 - 23 September 2016 21-23.

Malaysia Central Bank. (2017). http://www.bnm.gov.my

Meng, X., Hoang, N. T., \& Siriwardana, M. (2013). Journal of Asian Economics The determinants of Australian household debt : A macro-level study. Journal of Asian Economics, 29, 80-90.

Meniago, C., Mukuddem-petersen, J., Petersen, M. A., \& Mongale, I. P. (2013). What causes household debt to increase in South Africa ? Economic Modelling, 33, 482-492.

Mian, A., Sufi, A., \& Verner, E. (2016). Household Debt and Business Cycles Worldwide. Kreisman Working Papers Series in Housing Law and Policy No. 38.

Mutezo, A. (2014). Household debt and consumer spending in South Africa: an ARDL-bounds testing approach. Banks and Bank Systems, Vol 9

Nieto, F. (2007). The determinants of household credit in Spain. Banco de España Research Paper No.WP-0716. 
INTERNATIONAL JOURNAL OF ACADEMIC RESEARCH IN BUSINESS AND SOCIAL SCIENCES

Vol. 10, No. 5, May, 2020, E-ISSN: 2222-6990 @ 2020 HRMARS

Nick, T. G. (2007). Descriptive statistics. In Ambrosius W.T. (Ed.), Topics in Biostatistics, 33-52. New York: Springer.

Nizar, N. (2015). Determinants of Malaysia household debt: macroeconomic perspective. In Proceeding-Kuala Lumpur International Business, Economics and Law Conference, 1, 97-107.

Nomatye, A., \& Studies, E. (2017). Department Of Economics Working Papers Series.

Ntsalaze, L. (2017). The threshold effects of household indebtedness on multidimensional poverty. International Journal of Social Economics44(11), 1471-1488.

Oikarinen, E. (2008). Interaction between housing prices and household borrowing: The Finnish case. Journal of Banking \& Finance. 33(4), 747-756.

Meng, X., Hoang, N. T. \& Siriwardana, M. (2013). The determinants of Australian household debt: A macro-level study. Journal of Asian Economics, 29(C), 80-90.

Roberts, A. (2016). Household Debt and the Financialization of Social Reproduction: Theorizing the UK Housing and Hunger Crises. Risking Capitalism (Research in Political Economy, 31, 135-164.

Sánchez-martínez, M. T., Sanchez-campillo, J., \& Moreno-herrero, D. (2015). Mortgage debt and household vulnerability: Evidence from Spain before and during the global financial crisis, International Journal of Housing Markets and Analysis, 9(30), 400-420.

Sekaran, U., \& Bougie, R. (2013). Research Methods for Business (7th Editio). John Wiley \& Sons.

Settlements, I. (2009). BIS Papers Household debt : implications for monetary policy and financial stability.

Studenmund, A. H. (2006). Using Econometrics: A Practical Guide. Sixth Edition. Boston: Pearson.

Svensson, L. E. O. (2017). Leaning Against the Wind: Costs and Benefits, Effects on Debt, Leaning in DSGE Models, and a Framework for Comparison of Results. International Journal of Central Banking, 13(3), 385-408.

Ming-Yen Teoh, W., Chong, S., \& Yong, M. S. (2013). Exploring the factors influencing credit card spending behaviour among Malaysians. International Journal of Bank Marketing, 31(6), 481-500.

Terraneo, M. (2018). Households ' financial vulnerability in Southern Europe. Journal of Economic Studies, 45(3), 521-542.

The Star Online. (2020). Total household debt in Malaysia. The Star Online. Retrieved from https://www.thestar.com.my/business/business-news/2019/03/30/total-household-debt-inmalaysia

Turvey, C. G. (2009). Business and financial risks of small farm households in China. China Agricultural Economic Review, 1(2), 155-172.

World Bank Policy Research Report. (2014). WP-0716.

Worthington, A. C. (2009). The usage and understanding of Australian household mortgages. International Journal of Housing Markets and Analysis, 2(4), 347-362.

Xiao, J. J., \& Yao, R. (2014). Consumer debt delinquency by family lifecycle categories. International Journal of Bank Marketing, 32(1), 43-59.

Yahaya, S. N., \& Sarwe, N. A. (2019). The Impact of Macroeconomic Factors to Household Debt in Malaysia: A Theoretical Framework. International Journal of Human and Technology Interaction, 3(1), 87-94.

Kim, Y. (2011). The Macroeconomic Implications of Household Debt: An Empirical Analysis. Working Papers 1103, Trinity College, Department of Economics. 
INTERNATIONAL JOURNAL OF ACADEMIC RESEARCH IN BUSINESS AND SOCIAL SCIENCES

Vol. 10, No. 5, May, 2020, E-ISSN: 2222-6990 @ 2020 HRMARS

Zainol, Z., Daud, Z., Khairol, A. N. H., Rashid, R. A., \& Alias, N. (2016). Exploring factors that contribute to individual indebtedness among young Muslims. International Journal of Economics and Financial Issues, 6(7S), 320-328.

Zimunya, F. M., \& Raboloko, M. (2015). Determinants of household debt in Botswana: 1994-2012. Journal of Economics and Public Finance, 1(1), 14

Zocchi, P. (2011). Why do Italian households prefer adjustable-rate mortgages? Journal of European Real Estate Research, 6(1), 90-110. 